\title{
MICROCYSTIS SPECIES AND THEIR TOXIGENIC STRAINS IN PHYTOPLANKTON OF TEN BULGARIAN WATERBODIES
}

\section{Blagoy Uzunovi ${ }^{*}$, Katerina Stefanova ${ }^{2}$, Mariana Radkova ${ }^{2}$, Jean-Pierre DesCY ${ }^{3}$, Georg Gärtner ${ }^{4}$ and Maya Stoyneva-GärTneR ${ }^{1}$}

\author{
${ }^{1}$ Sofia University, Faculty of Biology, Department of Botany, Dragan Tsankov Blvd. 8, 1164 Sofia, Bulgaria \\ ${ }^{2}$ Bulgarian Agricultural Academy, AgroBioInstitute, Dragan Tsankov Blvd. 8, 1164 Sofia, Bulgaria \\ ${ }^{3}$ Université de Liège, Unité d'Océanographie Chimique, Sart Tilman, Allée du 6 août 19, 4000 Liège, Belgium \\ ${ }^{4}$ Institut für Botanik der Universität Innsbruck, Sternwartestrasse 15, 6020 Innsbruck, Austria \\ *Corresponding author. E-mail: buzunov@uni-sofia.bg
}

\begin{abstract}
Uzunov B., Stefanova K., Radkova M., Descy J.-P., Gärtner G., Stoyneva-Gärtner M., 2021: Microcystis species and their toxigenic strains in phytoplankton of ten Bulgarian waterbodies. - Botanica, 27(1): 77-94.

The summer phytoplankton structure of ten Bulgarian waterbodies was studied by HPLC analysis of marker pigments, light microscopy (LM) and PCR amplification of $m c y B$ and $m c y E$ gene sequences. The aim was to detect biodiversity and spread of toxigenic strains of potential microcystin producers and the important bloomforming genus Microcystis in particular. The screening was done in three waterbodies, where Microcystis had already been found (Lakes Ezerets and Durankulak and Reservoir Koprinka), three waterbodies from which it had not been reported (Reservoirs Shilkovtsi, Zhrebchevo, Suedinenie) and four reservoirs that were sampled for the first time (Malka Smolnitsa, Plachidol 2, Preselka, Duvanli). LM and HPLC data similarly showed that cyanoprokaryotes contributed significantly to the total phytoplankton composition (29\%) and biomass (15-87\%) in nine sampled waterbodies. Microcystis aeruginosa, M. natans, M. smithii, M. wesenbergii, Microcystis spp., M. cf. comperei and M. pseudofilamentosa, were identified using LM (the last two tropical species were found for the first time in the country). Despite the low contribution of Microcystis to the phytoplankton diversity (1-4 taxa per sample) and to the total phytoplankton biomass $(<0.01-0.5 \%), 57$ toxigenic strains of this genus were revealed by PCR, most of which demonstrated high similarity with NCBI M. aeruginosa and M. wesenbergii strains.
\end{abstract}

Keywords: algal blooms, alien species, cyanobacteria, cyanotoxins, lakes, microcystins, reservoirs.

\section{INTRODUCTION}

Scientific knowledge about Cyanoprokaryota/ Cyanobacteria (also known as blue-green algae) and environmental factors promoting their mass development (blooms), as well as their toxic metabolites (cyanotoxins) and primary toxin exposure vehicles (drinking water, recreational water activities, freshwater seafood) has rapidly advanced in recent times (Merel et al., 2013; Ibelings et al., 2014; Descy et al., 2016; Meriluoto et al., 2017; Flores et al., 2018). The most common and most frequently stud- ied cyanotoxins are the cyclic heptapetides microcystins, which occur in about 280 variants and are produced by several cyanoprokaryote genera (PELAEZ et al., 2010; Catherine et al., 2017; Meriluoto et al., 2017; Bouaicha et al., 2019; Le Manach et al., 2019; SvirČev et al., 2019; Massey et al., 2020; StoyneVA-GärTNER et al., 2021). One of these genera, $M i$ crocystis Kütz., is widely spread in the freshwater phytoplankton and contains more than 50 species (KomÁreK et al., 2014; Le MANACH et al., 2019; Guiry \& GuIRY, 2021) described according to the rules of the International Code of Nomenclature for Algae, 
Fungi and Plants (TuRLAND et al., 2018). However, opinions on the taxonomic validity of its species distinguished mainly by morphological criteria (morphospecies) differ from author to author (KOMÁREK et al., 2014; GuIRY \& GuIRY, 2021). These differences show the need for more polyphasic data with the maximum possible delimitation of the morphospecies in separate classification units (taxa) (KoRMAs et al., 2011; KомÁreK, 2016, 2018). There are also different opinions on the toxigenic potential of all Microcystis species, for some of which the ability for microcystin production is still unknown or has been questioned (Gkelis \& ZaOutsos, 2014; ŠeJnOHOVÁ \& MARŠÁLEK, 2012; KöKER et al., 2017; RADKOVA et al., 2020; StoyneVA-GÄrTnER et al., 2021 and references therein). The importance of studies of Microcystis and its blooms is growing considering that like other cyanoprokaryotes, they are favoured by anthropogenically enhanced eutrophication (Š́EJNOHOVÁ \& MaršÁleK, 2012; ZANChETT \& Oliveira-Filho, 2013; KomÁreK et al., 2014; Descy et al., 2016; Genuário et al., 2016; Le Manach et al., 2019; Wilhelm et al., 2020; Guiry \& Guiry, 2021), and are likely to expand their distribution, frequency and abundance with global warming (PAerl \& Huisman, 2008; CAREY et al., 2012; LehMAN et al., 2013; Wilhelm et al., 2020). Moreover, there is accumulating evidence that an increase of nutrient concentrations and water temperature may promote the potentially toxic Microcystis genotypes (VÉzIE et al., 2002; DAVIS et al., 2009; Joung et al., 2011; SRIVASTAVA et al., 2015; SCHERER et al., 2017; JANKOWIAK et al., 2019).

The present contribution is a continuation of our previous polyphasic studies of the bloom-forming genus Microcystis in Bulgaria (RADKOva et al., 2020; StOYNEVA-GÄRTNER et al., 2021). It presents new data on the diversity and spread of some Microcystis species and their strains containing microcystinsynthase genes ( $m c y$ genes). The paper reflects the contribution of Microcystis to the total phytoplankton of ten different Bulgarian waterbodies. They include two lakes and eight reservoirs important for public health and national security due to their use as drinking water supply or use for irrigation of vineyards and arable lands and their importance as recreational sites or use for sport-fishing and fishbreeding (Michev \& Stoyneva, 2007). In addition, some of these wetlands are significant for biodiver- sity conservation, and two of them are designated as Critically Endangered in the first Red List of Bulgarian Wetlands (Michev \& Stoyneva, 2007). From two of the waterbodies (coastal Lakes Durankulak and Ezerets), Microcystis has frequently been reported as a common phytoplankter (DESCY et al., 2018) and recently in Durankulak its toxigenic strains have been revealed by polyphasic approach (RADKOVA et al., 2020; STOYNEVA-GÄrTNER et al., 2021). In one of the large inland reservoirs (Koprinka), Microcystis was recorded at the end of the $80 \mathrm{~s}$. In contrast, from three other inland reservoirs (Shilkovtsi, Suedinenie and Zhrebchevo), Microcystis was not reported. Four other waterbodies (inland small Reservoirs Duvanli, Malka Smolnitsa, Plachidol 2 and Preselka) were sampled for the first time (Michev \& Stoyneva, 2007; StOYNEVA-GÄrTNER et al., 2017b).

This sampling design was applied because of three main reasons:

1) The polyphasic approach in cyanoprokaryote studies combines genetic evaluation with diagnostic criteria from morphological and ecological analysis (KoмÁrek, 2016), and, therefore, its application on the background of total phytoplankton composition and abundance, combined with environmental data, has been encouraged in studies on toxin producers (Rantala et al., 2006; Radkova et al., 2020; StoyneVA-GÄRTNER et al., 2021);

2) Despite that presence of toxin-producing cyanoprokaryotes, especially during blooms, leads to loss of ecosystem services (WILHELm et al., 2020), imposes a potential hazard to humans and wildlife, and in this way concerns also the national security, yet in Bulgaria, freshwater ecosystems are under no special monitoring for cyanotoxins (STOYNEVA-GÄRTNER et al., 2017a);

3) Cyanoprokaryote blooms (and this of Microcystis in particular) and their content are a strongly variable phenomenon, mainly depending on local conditions (Ibelings et al., 2014; Hartnell et al., 2020; Wilhelm et al., 2020), including the land use (SRIVASTAVA et al., 2015), which shows the need for accumulating of data from more waterbodies in each country. This is valid especially for Bulgaria, where all waterbodies cover $<1 \%$ of the country's territory and, due to their shallow character, are prone to cyanoprokaryote blooms (Michev \& Stoyneva, 2007). 


\section{MATERIALS AND METHODS}

\section{Sites and sampling}

The sampling was carried out between $14^{\text {th }}$ and $21^{\text {st }}$ August 2019 in ten waterbodies in Central and North-Eastern Bulgaria (Fig. 1, Table 1). In Table 1 , due to the significant variation in names of reservoirs in Bulgaria, we provide the unique number from the Inventory of Bulgarian Wetlands (Michev \& Stoyneva, 2007), where detailed descriptions of the waterbodies are available. However, it is worth mentioning that:

1) All studied reservoirs are inland plain waterbodies (except the lowland reservoir Suedinenie), while Lakes Durankulak (=Durankulashko Ezero) and Ezerets (=Ezeretsko Ezero) are coastal lowlands:

2) Coastal Lakes Durankulak and Ezerets are protected areas and are included in the Red List of Bulgarian Wetlands (Michev \& Stoyneva, 2007) in the category of Critically Endangered;

3) Reservoirs Koprinka (854 ha), Suedinenie
(159 ha), Shilkovtsi (=Yovkovtsi; 553 ha) and Zhrebchevo (1851 ha) are included in Appendix 1, "List of complex and significant reservoirs" of the Water Act (State Gazette 67/1999) (Michev \& StoyneVA, 2007);

4) Reservoirs Malka Smolnitsa, Plachidol 2, Preselka and Duvanli (=Duvanlii) are small reservoirs $(9,4,15$ and 27 ha, respectively);

5) Reservoirs Malka Smolnitsa, Plachidol 2, Preselka and Duvanli were sampled for the first time.

Before sampling, we observed each waterbody by a drone DJI Mavic 2 Enterprise Dual Pro, which could measure the surface water temperature and was supplied by a photo camera. In this way, spots with visible differences in colour were chosen for the sampling of cyanoblooms. In cases of visible water homogeneity, the sites from our previous studies were repeated (STOYNEVA-GÄRTNER et al., 2019; RADkOVA et al., 2020; Stefanova et al., 2020; StOYNEVAGÄRTNER et al., 2021) or, for the newly sampled small shallow reservoirs, the most accessible site was se-

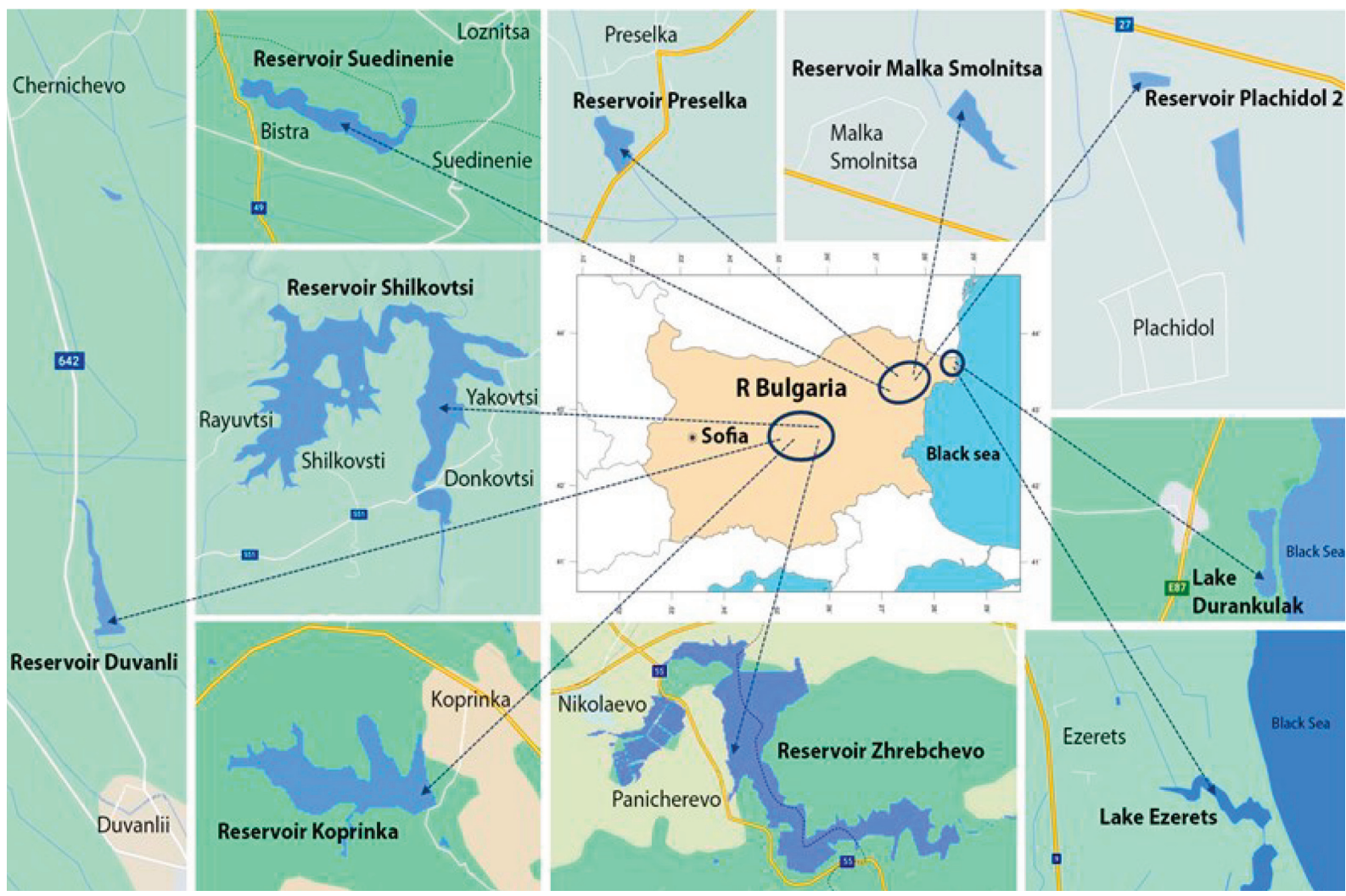

Fig. 1. Map of R. Bulgaria indicates the studied waterbodies (modified after (http://www.ginkgomaps.com and Google Maps) 
Table 1. Sampling sites (organised by the order of sampling, 14-20 August 2019) and their main environmental parameters. Legend: IBWXXXX - number of the waterbody in the Inventory of Bulgarian Wetlands (MicheV \& STOYNEVA, 2007); Alt altitude (m a.s.1.); WT - water temperature $\left({ }^{\circ} \mathrm{C}\right)$; $\mathrm{SD}$ - Secchi depth $(\mathrm{m})$; $\mathrm{CN}$ - conductivity $\left(\mathrm{S} \mathrm{m}^{-1}\right)$; TD - total dissolved solids $\left(\mu \mathrm{g} \mathrm{L}^{-1}\right)$; DO - oxygen concentration $\left(\mathrm{mg} \mathrm{L}^{-1}\right)$; $\mathrm{TP}$ - total phosphorus $\left(\mathrm{mg} \mathrm{L}^{-1}\right)$; $\mathrm{TN}$ - total nitrogen $\left(\mathrm{mg} \mathrm{L}^{-1}\right)$

\begin{tabular}{|c|c|c|c|c|c|c|c|c|c|c|}
\hline Waterbody & Alt & $\begin{array}{l}\text { Latitude / } \\
\text { Longitude }\end{array}$ & WT & $\mathrm{pH}$ & SD & $\mathrm{CN}$ & TD & DO & $\mathrm{TP}$ & $\mathrm{TN}$ \\
\hline Res. Shilkovtsi (IBW2105) & 410 & $\begin{array}{l}42^{\circ} 55.2320^{\prime} / \\
25^{\circ} 47.6743^{\prime}\end{array}$ & 27.2 & 8.88 & 0.5 & 0.000746 & 479 & 7.48 & 0.03 & 0.1 \\
\hline Res. Suedinenie (IBW2642) & 133 & $\begin{array}{l}43^{\circ} 20.0734^{\prime} / \\
26^{\circ} 33.6368^{\prime}\end{array}$ & 28.1 & 7.61 & 0.5 & 0.000739 & 481 & 6.77 & 0.10 & 0.3 \\
\hline Res. Preselka (IBW3078) & 281 & $\begin{array}{l}43^{\circ} 25.3767^{\prime} / \\
27^{\circ} 16.6214^{\prime}\end{array}$ & 24.1 & 9.00 & 0.5 & 0.000138 & 282 & 10.05 & 0.60 & 2.8 \\
\hline $\begin{array}{l}\text { Res. Malka Smolnitsa } \\
\text { (IBW3107) }\end{array}$ & 211 & $\begin{array}{l}43^{\circ} 36.2606^{\prime} / \\
27^{\circ} 44.5367^{\prime}\end{array}$ & 25.2 & 9.08 & 0.3 & 0.000755 & 490 & 7.05 & 0.60 & 0.63 \\
\hline Res. Plachidol 2 (IBW5073) & 220 & $\begin{array}{l}43^{\circ} 33.3504^{\prime} / \\
27^{\circ} 52.6338^{\prime}\end{array}$ & 24.6 & 9.04 & 0.5 & 0.001225 & 793 & 9.13 & 0.20 & 0.4 \\
\hline Lake Ezerets (IBW0233) & 6 & $\begin{array}{l}43^{\circ} 35.2681^{\prime} / \\
28^{\circ} 33.2096^{\prime}\end{array}$ & 25.9 & 8.58 & 1.5 & 0.001669 & 1739 & 8.58 & 0.10 & 0.1 \\
\hline $\begin{array}{l}\text { Lake Durankulak (IBW0216) - } \\
\text { western part }\end{array}$ & 2 & $\begin{array}{l}43^{\circ} 40.0006^{\prime} / \\
29^{\circ} 32.6166^{\prime}\end{array}$ & 26.5 & 8.89 & 0.6 & 0.000974 & 631 & 7.86 & 0.30 & 0.66 \\
\hline Res. Zhrebchevo (IBW2545) & 253 & $\begin{array}{l}42^{\circ} 36.6024^{\prime} / \\
25^{\circ} 51.2345^{\prime}\end{array}$ & 27.6 & 7.70 & 0.7 & 0.000358 & 233 & 8.01 & 0.10 & 0.18 \\
\hline Res. Koprinka (IBW2062) & 450 & $\begin{array}{l}42^{\circ} 37.0172^{\prime} / \\
25^{\circ} 19.4795^{\prime}\end{array}$ & 27.2 & 8.22 & 2.5 & 0.000250 & 163 & 7.21 & 0.10 & 0.16 \\
\hline Res. Duvanli (IBW1483) & 250 & $\begin{array}{l}42^{\circ} 23.1851^{\prime} / \\
24^{\circ} 43.1000^{\prime}\end{array}$ & 26.3 & 8.76 & 0.4 & 0.004050 & 291 & 7.09 & 0.10 & 0.25 \\
\hline
\end{tabular}

lected. The phytoplankton sampling was performed from inflatable boats. Data on geographical coordinates, altitude, water temperature, $\mathrm{pH}$, total dissolved solids, oxygen concentration, and conductivity were taken by the water monitoring instruments Aquameter AM-200 and Aquaprobe AP-2000. Water transparency was measured by Secchi disk. Aqualytic AL410 Photometer from AQUALYTIC $\circledR$ was used for ex situ measurement of total nitrogen (TN) and total phosphorus (TP) (STOYNEVA-GÄRTNER et al., 2019; RadKova et al., 2020; Stefanova et al., 2020; StOYNEVA-GÄrTnER et al., 2021). All obtained data are shown in Table 1.

The surface water layer $(0-20 \mathrm{~cm})$ samples for phytoplankton identification and counts $(0.5-1 \mathrm{~L}$ in volume, depending on the trophic state) were fixed immediately to $2 \%$ final formalin concentration and transported to the lab, where they were further concentrated by sedimentation to a volume of $50 \mathrm{ml}$ (RotT, 1981; StoYNEVA-GäRTNER et al., 2019, 2021; RADKOVA et al., 2020). Within a few hours after collection, the water samples for pigment analyses and PCR-studies (each in volume $0.5 \mathrm{~L}$ ) were filtered under a mild vacuum through Macherey-Nagel GF5 filters (MACHEREY-NAGEL GmbH \& Co. KG, Düren, Germany) with porosity $0.4 \mu \mathrm{m}$ and Whatman $0.45 \mu \mathrm{m}$ cellulose filters Whatman NC45 ST/ Sterile EO (Merck KGaA, Darmstadt, Germany), respectively. The filters were immediately placed in $15 \mathrm{~mL}$ sterile plastic tubes (Falcon) and preserved in dry ice to transport to the labs and further treatment.

\section{Phytoplankton species composition and abundan- ce assessment by conventional light microscopy (LM)}

The taxonomic work on the phytoplankton species composition was done using Motic B1 microscope under magnification $100^{\times}$and immersion. The microphotographic documentation was done by a Moticam $2.0 \mathrm{mp}$ camera supplied by Motic Images 2 Plus software programme. For algal counts from each site, at least four non-permanent slides were examined on Thoma counting chamber, with the abundance of each species estimated in both cell numbers and biomass, the last by using the stereometrical approximations and subsequent weight recalculation (Rott, 1981; Stoyneva et al., 2007; StoynevaGärtner et al., 2019; RadKova et al., 2020). 
The identification of phytoplankters followed standard taxonomic sources with updates from Algaebase (GUIRY \& GUIRY, 2021). The morphological diagnostic features used for species identification in the blue-green algal genus Microcystis were the traditionally used in phycological literature shape of the colony, presence/absence of subcolonies, density of cells in the colony, structure of the mucilage sheath, cell size and pigmentation, presence/absence of gas vesicles (GeItLER, 1931, 1942; GollerbaKh et al., 1953; STARMACH, 1966; KomÁReK \& KomÁRKovÁ, 2002; KomÁreK \& ANAGnostidis, 1998). Following the instructions in KoMÁReK \& ANAGNOSTIDIS (1998), the ecological characteristics of the species were taken into account as an integral part of the species characterisation. The list of potential microcystinproducers followed mainly CATHERINE et al. (2013), Bernard et al. (2017), Lyon-Colbert et al. (2018) and CHAPMAN \& Foss (2020).

\section{Phytoplankton composition assessment by HPLC marker pigment analysis}

This procedure was applied for the determination of the general phytoplankton composition based on the chlorophyll $a$ biomass of the main algal groups, namely green algae (from both phyla Chlorophyta and Streptophyta), cryptophytes, pyrrhophytes (dinoflagellates), euglenophytes and cyanoprokaryotes (two pigment types, cyanoprokaryotes $\mathrm{T} 1$ and $\mathrm{T} 2$ ), and two classes of phylum Ochrophyta - golden algae (Chrysophyceae) and diatoms (Bacillariophyceae).

All steps of the performed HPLC analysis and subsequent application of CHEMTAX (MACKEY et al., 1996; Wright \& Jefrrey, 2006; Sarmento \& DESCY, 2008; DESCY, 2017) followed the standard procedures and coincided entirely with the detailed description provided in our former papers (STOYNEVA-GÄrTNER et al., 2019, 2021).

\section{Molecular-genetic studies}

In the lab, the metagenomic DNA was isolated from the ex situ filters obtained after sampling in the field, following GeneJET ${ }^{\mathrm{TM}}$ Plant Genomic DNA Purification Mini Kit (Thermo Scientific, Waltham, MA, USA). In our previous work, we have performed the sequence analysis of PCR amplified fragments of the target $m c y B$ and $m c y E$ genes, known for their reliable microcystin-detective biomarker character (STOYNE-
VA-GÄrTNER et al., 2021; and references therein). All amplifications were carried out in the thermal cycler (QB-96 apparatus, Quanta Biotech), in a final volume of $25 \mu \mathrm{l}$, using MyTaqHS Mix PCR. Still, here we point again the synthetase-gene-specific pairs of primer applied and the relevant annealing temperatures: for the PCR amplification of $m c y B$ gene - MIf GCAGCGAACTCTTGAAGGGTTTATG and MIr GCGGATTCTGTGCAGCTTGTTCTTC, 850 bp, $55^{\circ} \mathrm{C}$ (Foulds et al., 2002) and for the $m c y E$ gene HEPF (5'TTTGGGGTTAACTTTTTT3GGGCAT AGTC-3') $\times$ HEPR (5'AATTCTTGAGGCTGTAA ATCGGGTTT-3') 470 bp, 57² C (Jungblut \& NeILAN, 2006).

The obtained $m c y E$ and $m c y B$ sequences were assembled, manually edited, analysed using Vector NTI 11.5 software, and used for Basic Local Alignment Search Tool (BLAST) search (BLAST, 2021) in the National Centre for Biotechnology Information (NCBI) genetic database (NCBI, 2021). Then, Mega 6.06 software was applied to construct a phylogenetic tree based on the Neighbour-joining method with 1000 bootstrap replication (TAMURA et al., 2013). There, the accession numbers of 37 (out of the obtained 51) $m c y E$-based strains (MW602416MW602424, MW602426-MW602453) and six $m c y B$-based strains (MW602454-MW602459), newly submitted by us to NCBI, are shown in brackets. In the text, the taxonomic identification number in NCBI (NCBItxidXXXXXX) is also indicated.

\section{RESULTS}

\section{Phytoplankton species composition and abundan- ce, obtained by light microscopy (LM)}

A total of 212 species were identified using LM in the phytoplankton of the ten studied waterbodies. They belonged to seven algal phyla, namely Cyanoprokaryota, Chlorophyta, Streptophyta, Ochrophyta, Cryptophyta, Pyrrhophyta and Euglenophyta (Fig. 2). Cyanoprokaryotes comprised $29 \%$ of the total biodiversity and were represented by 62 taxa from 33 genera. Some species from the genera Aphanothece, and Microcystis (Chroococcales), Merismopedia, Limnothrix, Jaaginema, Pseudanabaena, Snowella, Synechococcus and Synechocystis (Synechococcales), Anagnostidinema, Geitlerinema, Oscillatoria and Planktothrix (Oscillatoriales), Anabaena s.str., 
Aphanizomenon s.str., Chrysosporum, Dolichospermum and Raphidiopsis (incl. former Cylindrospermopsis) (Nostocales) are known as microcystin producers (CATHERINE et al., 2013; Bernard et al., 2017; Lyon-Colbert et al., 2018; Chapman \& Foss, 2020).

Cyanoprokaryotes have an essential contribution to the total phytoplankton biodiversity, occupying the second position after green algae (from both divisions Chlorophyta and Streptophyta) or Ochrophyta (mainly diatoms) in almost all studied waterbodies (Figs 3, 4). The single exception is the drinking-water reservoir Shilkovtsi, in which the representatives of this taxonomic group were not detected (Figs 3, 4).

The total number of phytoplankton species in the

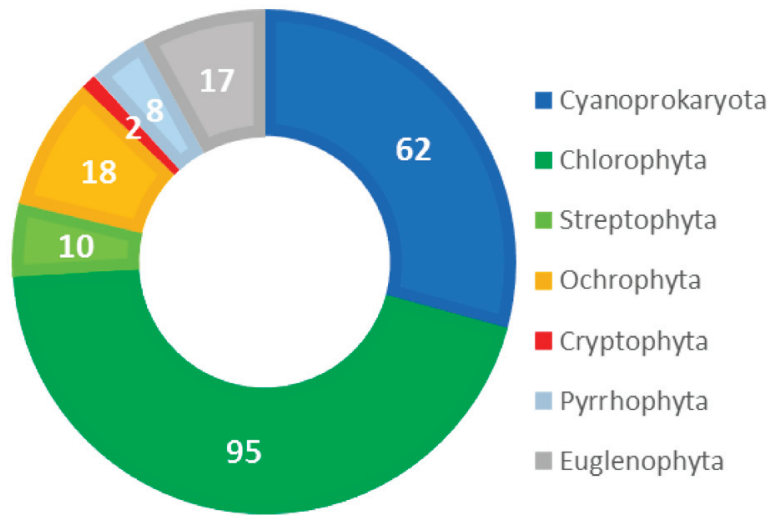

Fig. 2. General phytoplankton species composition in ten Bulgarian wetlands sampled in August 2019. The number of identified taxa in each phylum is indicated studied waterbodies ranged between 16 (Reservoir Shilkovtsi) and 65 (Reservoir Duvanli) (Fig. 4). The number of cyanoprokaryotes was between two (Lake Ezerets) and 21 (Reservoir Duvanli), considering that they were not observed in Shilkovtsi (Fig. 4). Microcystis was represented in all waterbodies (except Shilkovtsi) with a low number of taxa ranging between 1 (Reservoir Suedinenie and Lake Ezerets) and five (Reservoir Duvanli) (Fig. 4, Table 2).

Cyanoprokaryotes comprised from 15 (Lake Ezerets and Reservoir Koprinka) to 89\% (Reservoir Malka Smolnitsa) of the total phytoplankton biomass, except in Reservoir Shilkovtsi (Fig. 5). It has to be noted that their blooms dominated by a single species were not detected, and Microcystis did not appear as dominant, codominant or subdominant. In Reservoirs Duvanli, Malka Smolnitsa and Preselka, the phytoplankton was polydominated with the contribution of filamentous cyanoprokaryotes (mainly heterocytous Anabaenopsis, Raphidiopsis, Sphaerospermopsis and non-heterocytous Pseudanabaena and Planktolyngbya).

Considering the results on toxigenic strains obtained by PCR analysis, we present the LM data on the genus Microcystis. Based on the traditional diagnostic features (GeItLer, 1931, 1942; GollerbaKh et al., 1953; Starmach, 1966; KomÁreK \& KomÁrKovÁ, 2002; KomÁrek \& AnAgnostidis, 1998), we identi-

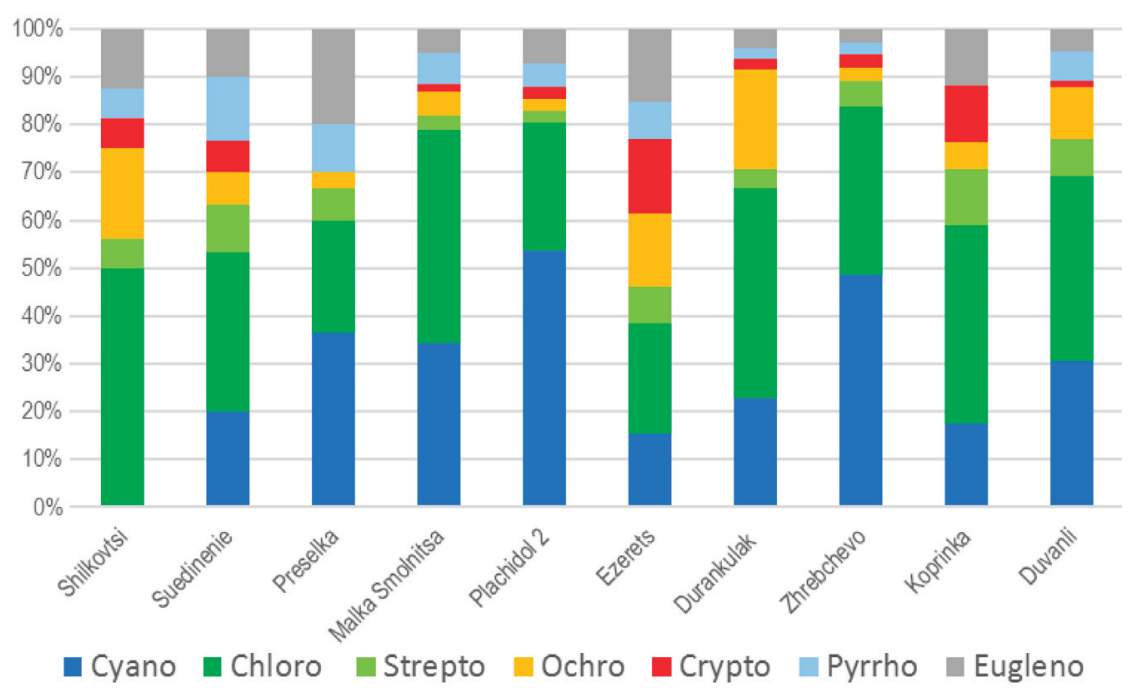

Fig. 3. The relative contribution of different taxonomic groups to the phytoplankton biodiversity according to the number of species obtained by light microscopy in the studied Bulgarian waterbodies (August 2019). Legend: Cyano - Cyanoprokaryota, Chloro - Chlorophyta, Strepto - Streptophyta, Ochro - Ochrophyta, Crypto - Cryptophyta, Pyrrho - Pyrrhophyta and Eugleno - Euglenophyta 
Table 2. Distribution of Microcystis taxa identified by LM and their contribution to the total phytoplankton biomass in the studied Bulgarian waterbodies (WBs) in August 2019: MA - Microcystis aeruginosa, MC - Microcystis cf. comperei, MN Microcystis natans, MP - Microcystis pseudofilamentosa, MS - Microcystis smithii, MSp - Microcystis sp., MW - Microcystis wesenbergii, SS/DC - separate cells or disintegrated colonies, TTs - colonies with transitional morphology (for details see the text of the paper), n.d. - not detected

\begin{tabular}{|l|c|c|c|c|c|c|c|c|c|}
\hline \multicolumn{1}{|c|}{ Waterbody } & MA & MC & MN & MP & MS & MW & MSp & SS/DC & TTs \\
\hline Res. Shilkovtsi & n.d. & n.d. & n.d. & n.d. & n.d. & n.d. & n.d. & n.d. & n.d. \\
\hline Res. Suedinenie & n.d. & n.d. & n.d. & n.d. & n.d. & n.d. & n.d. & $<0.05 \%$ & n.d. \\
\hline Res. Preselka & n.d. & n.d. & n.d. & n.d. & n.d. & $<0.5 \%$ & $<0.05 \%$ & $<0.05 \%$ & n.d. \\
\hline Res. Malka Smolnitsa & n.d. & n.d. & n.d. & $<0.1 \%$ & $<0.1 \%$ & $<0.05 \%$ & n.d. & $<0.05 \%$ & $<0.05 \%$ \\
\hline Res. Plachidol 2 & n.d. & n.d. & n.d. & n.d. & n.d. & $<0.1 \%$ & n.d. & $<0.1 \%$ & n.d. \\
\hline Lake Ezerets & n.d. & n.d. & n.d. & n.d. & n.d. & n.d. & n.d. & $<0.05 \%$ & n.d. \\
\hline Lake Durankulak & n.d. & n.d. & n.d. & n.d. & n.d. & n.d. & n.d. & $<0.05 \%$ & $<0.05 \%$ \\
\hline Res. Zhrebchevo & $<0.5 \%$ & n.d. & $<0.05 \%$ & n.d. & n.d. & n.d. & n.d. & $<0.05 \%$ & n.d. \\
\hline Res. Koprinka & $<0.5 \%$ & & n.d. & n.d. & n.d. & n.d. & n.d. & $<0.05 \%$ & n.d. \\
\hline Res. Duvanli & n.d. & $<0.01 \%$ & $<0.1 \%$ & n.d. & n.d. & $<1 \%$ & n.d. & $<0.1 \%$ & $<0.05 \%$ \\
\hline
\end{tabular}

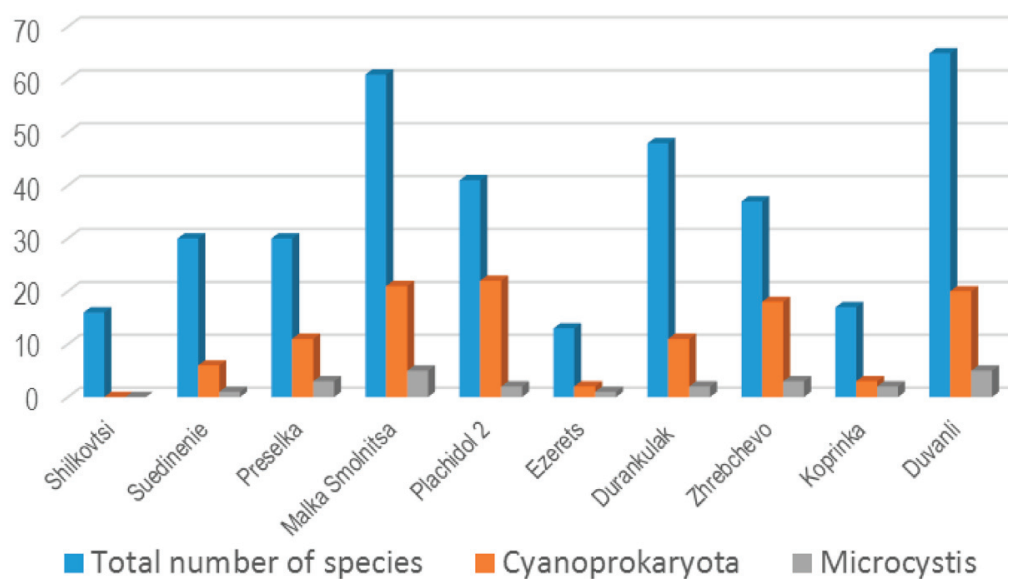

Fig. 4. Biodiversity in the studied Bulgarian waterbodies (August 2019) obtained by light microscopy and expressed as the total number of species, number of Cyanoprokaryota species and number of Microcystis morphospecies

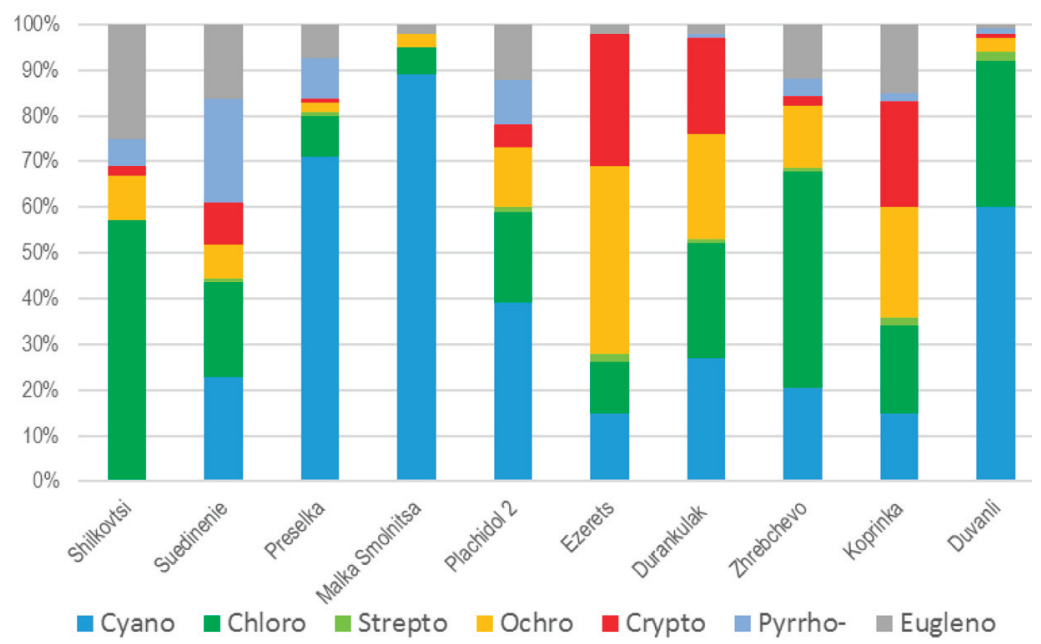

Fig. 5. The relative contribution of different taxonomic groups to the total phytoplankton biomass, obtained by light microscopy, in the phytoplankton of the studied Bulgarian waterbodies (August 2019). Legend: Cyano - Cyanoprokaryota, Chloro Chlorophyta, Strepto - Streptophyta, Ochro - Ochrophyta (mainly diatoms), Crypto - Cryptophyta, Pyrrho - Pyrrhophyta and Eugleno - Euglenophyta 
fied six species: M. aeruginosa (Kütz.) Kütz., M. cf. comperei Komárek, M. natans Lemmerm. ex Skuja, M. smithii Komárek \& Anag., M. pseudofilamentosa W. B. Crow, M. wesenbergii (Komárek) Komárek, distinguished one more morphospecies, which could not be referred to any known species and presented here as Microcystis sp. (Figs 6-9; Table 2). Regarding $M$. comperei, we would like to note that few colonies were found in the samples from Reservoir Duvanli, with smaller dimensions $(2.5-3 \mu \mathrm{m}$ in diameter) than indicated for the species $(4.5-5.2 \mu \mathrm{m})$ (KomÁreK, 1984; KomÁreK \& ANAgnostidis, 1998), but very consistent with the other species features and with the records, published from Yukatan (TAVERA et al., 2013 (p. 42, Fig. 62)). These colonies slightly resemble the initial stages of $M$. smithii, but the scattered cells are more typical for this species. Therefore, until more data are accumulated, we refer to the material from Duvanli as $M$. cf. comperei. In some samples, we also found separate cells, disintegrated colonies, or initial colonies and colonies with transi- tional morphology, for which species identification was not possible (Figs 6-8; Table 2). Microcystis distribution was different in the studied waterbodies, and its contribution to the total phytoplankton biomass was extremely low - between $<0.05 \%$ and $0.5 \%$ (Table 2).

The highest diversity of colonies and single cells was observed in Reservoirs Duvanli, Malka Smolnitsa, Plachidol 2 and Preselka.

\section{Results on general phytoplankton composition from HPLC analysis of marker pigments}

According to HPLC data on marker pigments, the majority of phytoplankton in the studied waterbodies consisted of Cyanoprokaryota, green algae (Chlorophyta and Streptophyta) and Ochrophyta (mainly Bacillariophyceae and less Chrysophyceae) and a smaller part Cryptophyta, Euglenophyta and Pyrrhophyta (Fig. 10).

The chlorophyll $a$ values, measured by HPLC, indicated the meso- to hypertrophic status of the stud-
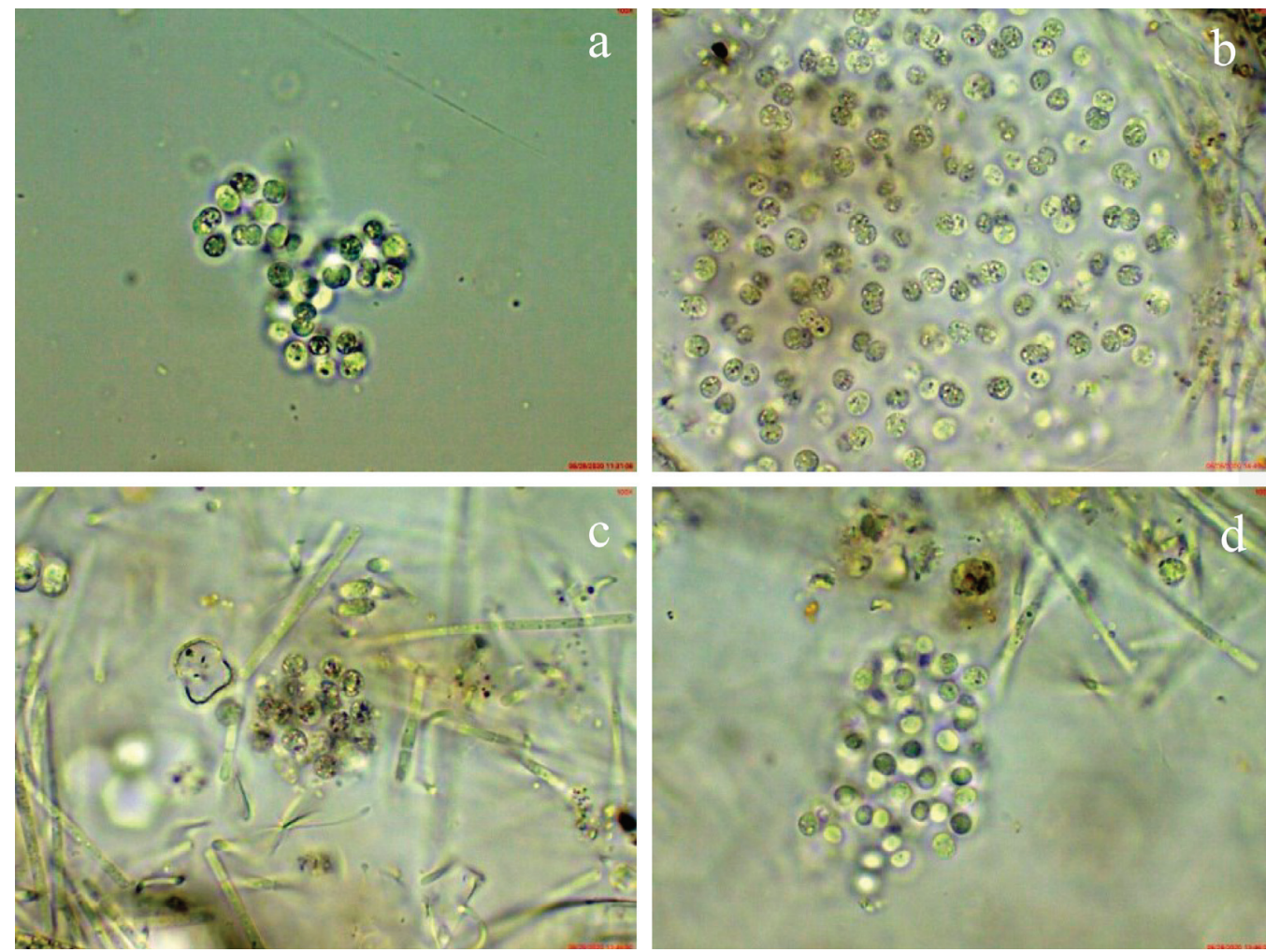

Fig. 6. Microcystis from different Bulgarian waterbodies (under immersion and objective 100×). Sample from Reservoir Preselka: (a) Microcystis sp. Samples from Reservoir Malka Smolnitsa: (b) M. smithii (c) Initial colony with densely packed cells and without clearly visible mucilage (which could be tentatively referred to M. aeruginosa); (d) M. pseudofilamentosa. The scale bar on all photos is $10 \mu \mathrm{m}$ 

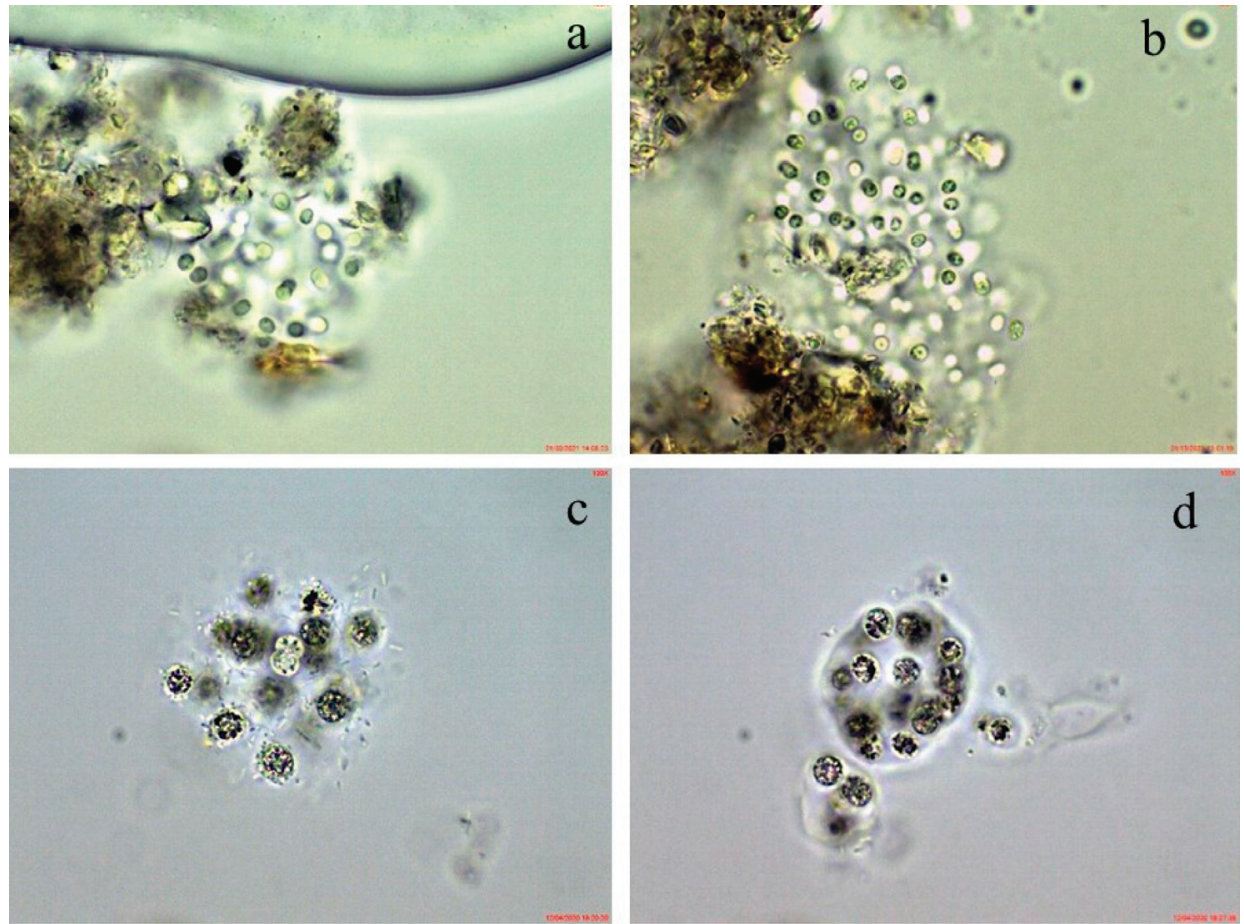

Fig. 7. Microcystis from different Bulgarian waterbodies (under immersion and objective $100 \times$ ). Samples from Reservoir Zhrebchevo: (a, b) M. natans. Samples from Reservoir Plachidol 2: (c) initial (?) colony, which could be tentatively related to M. aeruginosa; (d) M. wesenbergii. The scale bar on all photos is $10 \mu \mathrm{m}$
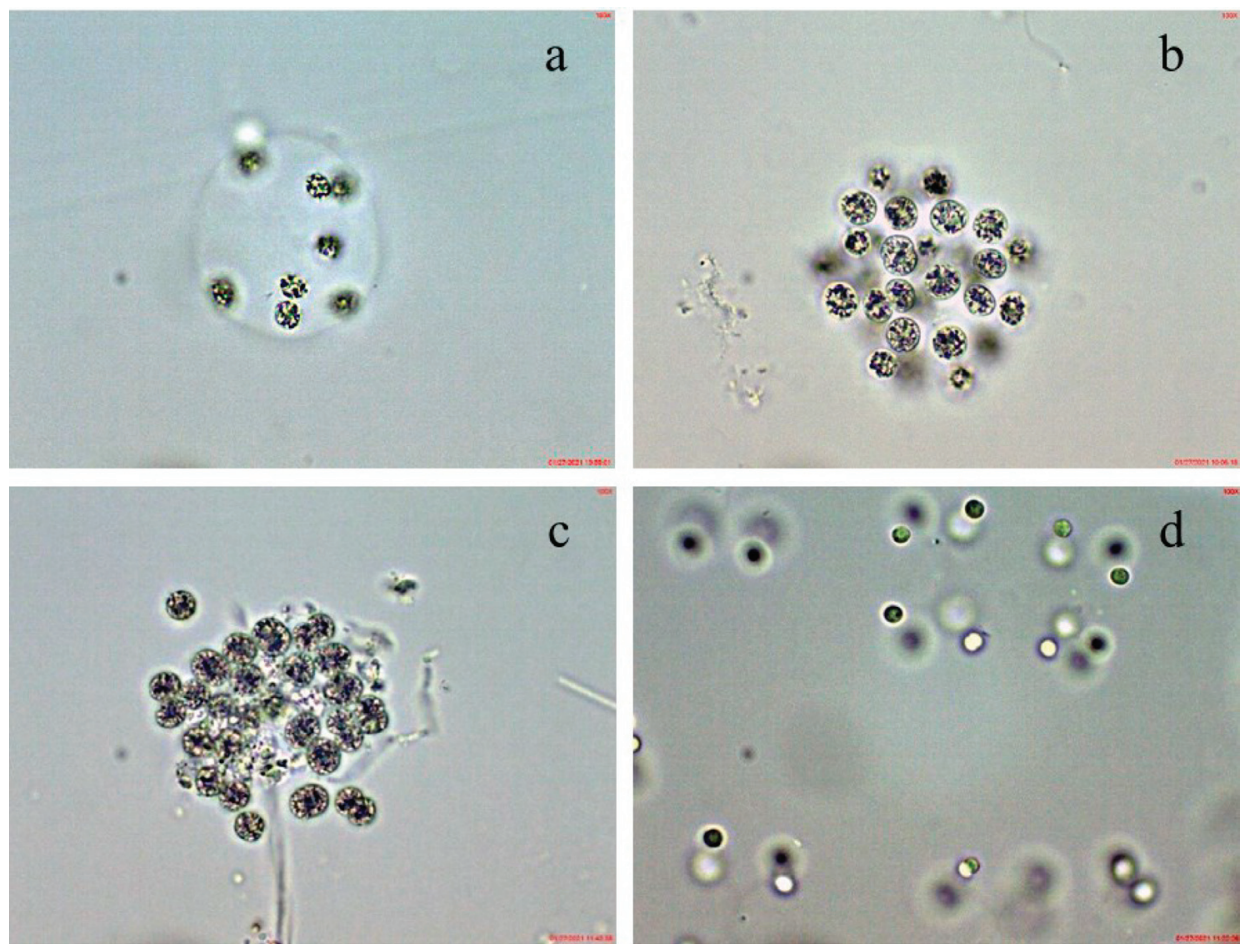

Fig. 8. Microcystis from different Bulgarian waterbodies (under immersion and objective 100×). Samples from Reservoir Duvanli: (a) M. wesenbergii - juvenile, but typical colony with a small number of cells; $(b, c)$ initial colonies with invisible mucilaginous margin, transitional between $M$. wesenbergii and M. aeruginosa; (d) disintegrating colony. The scale bar on all photos is $10 \mu \mathrm{m}$ 

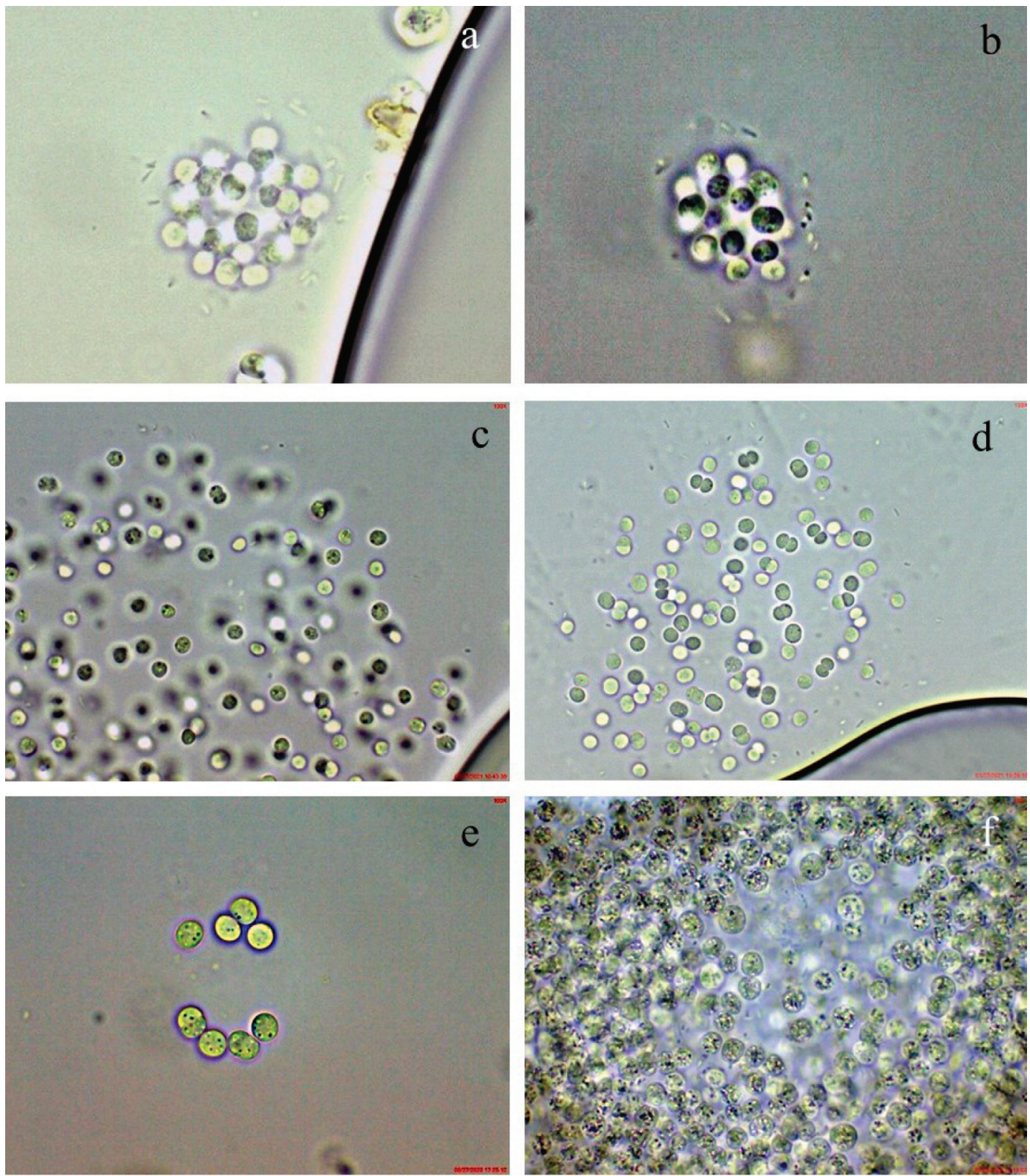

Fig. 9. Microcystis from different Bulgarian waterbodies (under immersion and objective 100×). Samples from Reservoir Duvanli: (a, b) M. cf. comperei; (c) Microcystis natans; (d) Microcystis cf. natans. Sample from Lake Durankulak (western part): (e) juvenile colony could be tentatively related to $M$. wesenbergii due to the lack of thickened mucilage outline. Sample from Reservoir Koprinka: (f) M. aeruginosa. The scale bar on all photos is $10 \mu \mathrm{m}$

ied waterbodies, in agreement with the Secchi disk depth and TP data (Table 1). The chlorophyll $a$ values ranged from 1.5 (Reservoir Koprinka) to $26 \mu \mathrm{g}$ $\mathrm{L}^{-1}$ (Reservoir Duvanli) and were significantly higher only in Reservoirs Preselka and Malka Smolnitsa, where they were 113 and $101 \mu \mathrm{g} \mathrm{L}^{-1}$, respectively. In the last three reservoirs, cyanoprokaryotes had the highest contribution to the phytoplankton (Fig. 10).

\section{Results from PCR analysis for microcystin-pro- ducing strains}

The generic microcystin-synthetase gene $\mathrm{E}(m c y E)$ was successfully amplified in nine from the ten metagenomic DNA samples, and 51 sequences were obtained. They and their corresponding high homologous (98$100 \%$ ) NCBI (NCBI, 2021) sequences are presented on the constructed $m c y E$ phylogenetic tree (Fig. 11). 


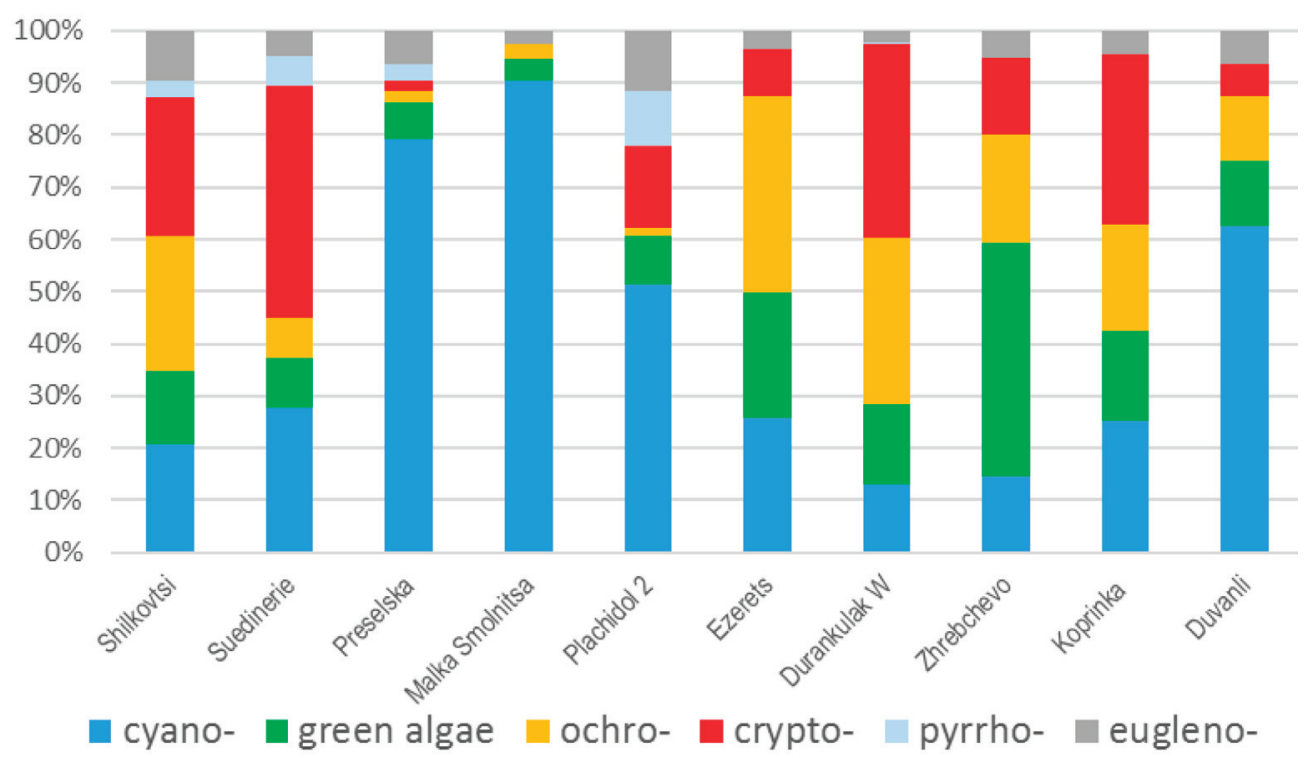

Fig. 10. General phytoplankton composition according to the pigment markers analysed by HPLC (expressed as percentage contribution to chlorophyll $a$, calculated using CHEMTAX) in the ten studied Bulgarian waterbodies (August 2019). Legend: cyano - cyanoprokaryotes, green algae - chlorophytes and streptophytes, ochro - ochrophyta (incl. diatoms and golden algae), crypto - cryptophytes, pyrrho - pyrrhophytes and eugleno - euglenophytes

The primary grouping was around the NCBI strains of two Microcystis species - M. aerugino$s a$ and $M$. wesenbergii (Fig. 11). Detailed analysis showed that eight sequences from Lake Durankulak, Reservoirs Preselka and Koprinka were 100\% homologous with $M$. aeruginosa (and two sequences from Reservoirs Koprinka and Zhrebchevo (Kop 1 and Zhr 1) were $100 \%$ homologous with $M$. wesenbergii NIES-107 (NCBI:txid315483). Other 18 strains from Lakes Durankulak and Ezerets and from Reservoirs Duvanli, Koprinka, Malka Smolnitsa, Preselka and Zhrebchevo had high homology with NCBI M. aeruginosa strains. Two strains from Preselka (Pre 1 and Pre 4) showed high similarity with $M$. viridis NIES102 (NCBI:txid213615). The rest of the strains had similarity with cultured and uncultured Microcystis NCBI strains, which were not supplied by species names (Fig. 11). Despite general grouping in a single cluster, the obtained $m c y E$ sequences were diverse, spread in three subclusters and demonstrated the rich biodiversity of toxigenic Microcystis strains in the studied waterbodies.

By applying direct sequencing based on $m c y B$ marker, six sequences from Lake Ezerets and Reservoirs Duvanli, Koprinka, Malka Smolnitsa, Preselka and Zhrebchevo were obtained and included in the constructed phylogenetic tree with Fischerella as outgroup
(Fig. 12). They belonged to a single cluster and were affiliated with a single Microcystis viridis Nies-102 strain and six M. aeruginosa strains registered in NCBI (NCBI, 2021). However, the $m c y B$ sequences from Lake Durankulak and Reservoirs Plachidol 2 and Suedinenie were not clear and were not included in this tree.

\section{DISCUSSION}

The results on general phytoplankton composition revealed by marker pigment analysis (Fig. 10) are consistent with the taxonomic groups in phytoplankton species composition (Figs 3,4) and their contribution to the biomass (Fig. 5) identified by LM. The single discrepancy in the results concerned the drinking water Reservoir Shilkovtsi in which cynoprokaryotes were not found by LM. It could be explained by finding by HPLC of cyanoprokaryote pigments of "Synechococcus pigment type" (T1) typical for picoplankters, which could not be seen by LM (Figs 4, 5).

Generally, both HPLC data on marker phytoplankton pigments and LM counts demonstrated the high proportion of cyanoprokaryotes in the quantitative structure of the summer phytoplankton of the other studied waterbodies (Figs 5, 10). These data fit with the well-established notion that cyanoprokary- 


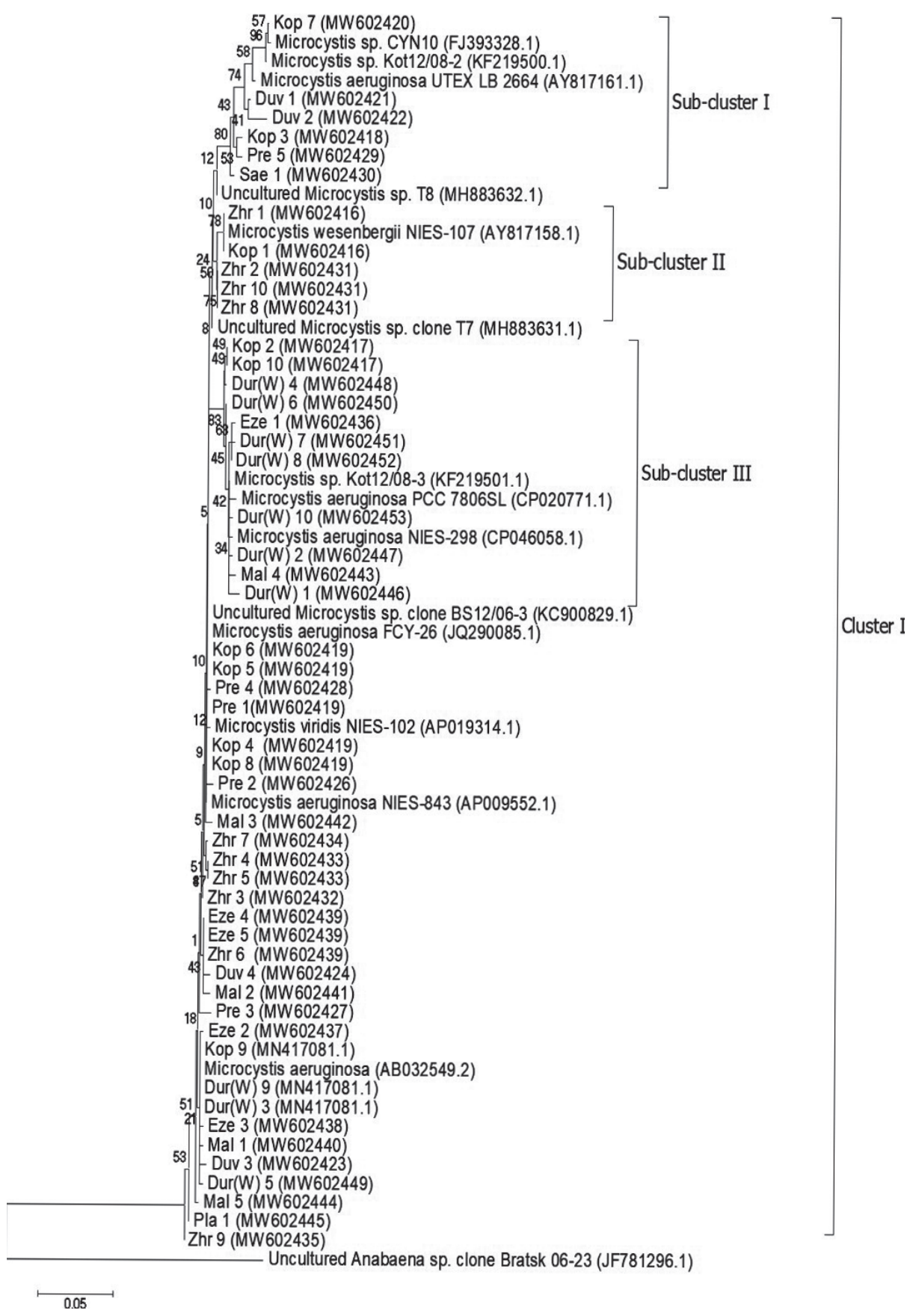

Fig. 11. Neighbour-joining phylogenetic tree constructed using nucleotides sequences from nine library samples and closest sequences in NCBI database with their accession number there, and with Uncultured Anabaena sp. JF781296.1 as outgroup. Bootstrap values are shown at branch points (percentage of 1050 resamplings). Legend: Duv - Reservoir Duvanli; Dur (W) Lake Durankulak, western part; Eze - Lake Ezerets; Kop - Reservoir Koprinka; Mal - Reservoir Malka Smolnitsa; Pre - Reservoir Preselka; Sae - Reservoir Suedinenie; Zhr - Reservoir Zhrebchevo. For the identical sequences (IS), obtained during this study, only one accession number received from NCBI is provided: 1) IS from Koprinka and Zhrebchevo (Kop 1 and Zhr 1) have accession number MW602416; 2) IS from Koprinka and Preselka (Kop 4, Kop 5, Kop 6, Kop 8 and Pre 1) have accession number MW602119; 3) IS from Koprinka (Kop 2 and Kop 10) have MW602417; 4) IS from Zhrebchevo (Zhr 2, Zhr 8, Zhr 10) have MW602431, and Zhr 4 and Zhr 5 have MW602433); 5) IS from Ezeretz and Zhrebchevo (Eze 4, Eze 5 and Zhr 6) have accession number MW602439; 6) IS from Durankulak (Dur (W) 3 and Dur (W) 9) have accession number MN417081.1, because these sequences are identical with the strain Dur2_10 MN417081.1 submitted earlier by us (RADKOVA et al., 2020) 


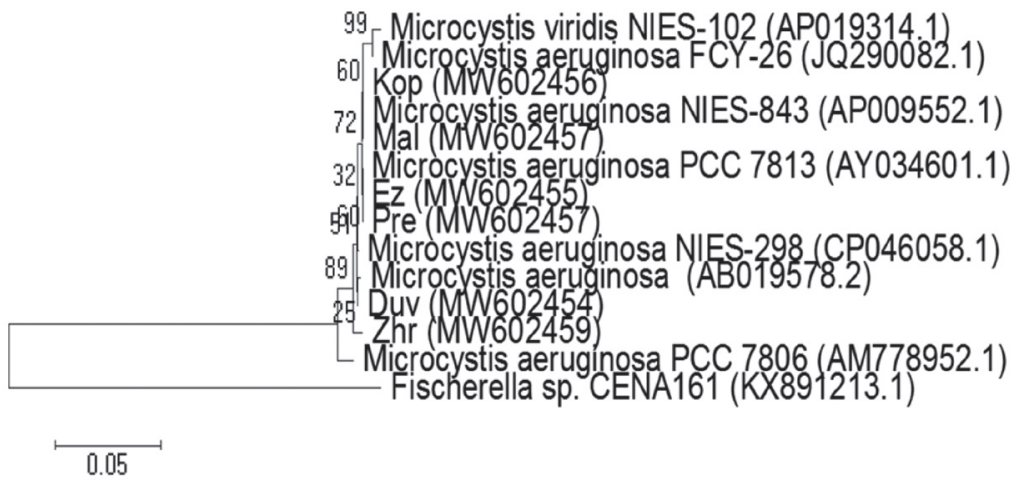

Fig. 12. Neighbour-joining phylogenetic tree based on nucleotides sequences from direct sequencing of PCR products and $m c y B$ marker, constructed after BLAST search in NCBI database with Fischerella sp. KX891213.1 as outgroup. Bootstrap values are shown at branch points (percentage of 1050 resampling). Legend: Duv - Reservoir Duvanli; Ez - Lake Ezerets; Kop - Reservoir Koprinka; Mal - Reservoir Malka Smolnitsa; Pre - Reservoir Preselka; Zhr - Reservoir Zhrebchevo

ote bloom occurrence is more widespread during periods when light intensities and water temperatures are higher (TURNER et al., 2018). This general result is following the statement for the summer cyanoprokaryote dominance as a common feature of eutrophic waterbodies worldwide (REYNOLDS, 2006; Lymperopoulou et al., 2011; Whitton, 2012) and in Bulgaria in particular (STOYNEVA-GÄRTNER et al., 2017b, 2019, 2021; Descy et al., 2018).

The LM analysis revealed seven morphospecies, among which $M$. aeruginosa and $M$. wesenbergii were most widespread (Figs 5-9, Table 2). These data are in accordance with our results for nine other sites, sampled during the same campaign in August 2019, which pointed $M$. aeruginosa and $M$. wesenbergii as primary microcystin-producers (STOYNEVA-GäRTNER et al., 2021). Despite the rich phytoplankton diversity (212 taxa from seven algal phyla - Fig. 2) and finding of species from almost all cyanoprokaryote genera, known as potential microcystin-producers (Catherine et al., 2013; Bernard et al., 2017; LyonColbert et al., 2018; Chapman \& Foss, 2020), $m c y B$ and $m c y E$ genes were identified only in Microcystis strains (Figs 11-12). Moreover, data obtained by PCR amplification demonstrated the high biodiversity of potentially toxigenic Microcystis strains, the coexistence of several strains in the studied waterbodies, and their unequal geographic distribution in the country. They once more confirmed $M$. wesenbergii as a potential microcystin-producer (NAMIKOSHI et al., 1992; Š́JNoHovÁ \& MARŠÁLeK, 2012; PAVlova et al., 2014; KöKer et al., 2017; StOYNEVA-GÄrTnER et al., 2017b, 2021; ChAPMAN \& Foss, 2020; RAdKovA et al., 2020) in addition to the best-known producer of this toxin $-M$. aeruginosa. The delimitation of $M$. aeruginosa and $M$. wesenbergii strains by their $m c y E$ toxigenic sequences in our study is in agreement with general phylogenetic distinction in two groups based on 16S-23S ITS fragments $(>600 \mathrm{bp}$ long) (Le Manach et al., 2019).

Our results are consistent with the opinions about the infrageneric diversity of Microcystis and its uneven geographical distribution, shared in earlier works (Le Manach et al., 2019) and with our results in both previous studies (RAdKova et al., 2020; StoynevaGÄRTNER et al., 2021). The PCR analysis on $m c y E$ and $m c y B$ gene also demonstrated the high similarity of strains from Reservoirs Koprinka, Malka Smolnitsa and Preselka with two genetically identical NCBI strains of $M$. viridis, namely strains $M$. viridis NIES-102 (NCBI:txid213615) and $M$. viridis NIES843 (NCBI:txid449447), from which only the first is shown on the trees (Figs 11-12). This morphospecies was not identified by LM in any of the studied waterbodies, but in the abovementioned lakes and reservoirs, single cells, juvenile or disintegrated colonies were seen (Table 2), the identification of which was practically impossible.

The results from PCR analysis did not allow us to relate the other five Microcystis taxa, which we identified based on morphology, with NCBI strains, which shows the necessity of further studies for revealing presence/absence of toxigenic strains in $M$. natans, M. novacekii and M. smithii. In the last two species, microcystin-producing strains have been rarely found (Liu et al., 2011; BERNARD et al., 2017; 
Chapman \& Foss, 2020). The existence of such strains in Bulgarian waterbodies has been tentatively supposed only for $M$. natans in our earlier studies (RADKOVA et al., 2020). We could not refer any of the obtained mcy sequences to the two tropical species, $M$. cf. comperei and M. pseudofilamentosa, found by LM for the first time in Bulgaria during this study. The occurrence of each of them in a single site (Reservoirs Duvanli and Malka Smolnitsa, respectively) in deficient amounts allows us to suggest their alien character for the country.

Despite the finding of toxigenic strains of $\mathrm{Mi}$ crocystis, we have to note that in the water samples collected during the same sampling campaign, microcystins (-LR, RR and YY) were not chemically detected (StoynEVA-GärTNER et al., 2021). Considering that amounts and dynamics of cyanotoxins in the water are generally related to the population dynamics of their producers (KARDINAAL et al., 2007; LEHMAN et al., 2013), but in some cases, strong correlations with Microcystis biomass have not been found, because not all cells produce toxins (DAvis et al., 2009), the explanation can be found in the extremely low contribution of all Microcystis cells (both morphologically indistinguishable toxic and non-toxic cells) to the total phytoplankton.

\section{CONCLUSIONS}

The present study revealed seven morphospecies of Microcystis and 57 toxigenic strains of this genus in nine of ten sampled waterbodies. Although they were detected in low amounts during the single sampling campaign, their presence can serve as an alarm signal for the potential risk for human and environmental health in the investigated reservoirs and lakes. The study highlights the positive effect of applying molecular-genetic methods to detect potential toxinproducers even when they are at low abundance in the phytoplankton. At the same time, the impossibility to refer most of the strains to known Microcystis species once more demonstrates the necessity of providing detailed morphological descriptions and illustrative documentation to the strains supplied to NCBI, to get a better view of the taxonomy and global distribution of essential cyanoprokaryotes as Microcystis.

The high summer contribution of cyanoprokaryotes to the total phytoplankton diversity and biomass, confirmed by both LM and HPLC analyses, and the unequal spread of toxigenic strains supports all previously expressed opinions on the need for implementing a broader monitoring programme of harmful cyanoblooms in the country.

\section{ACKNOWLEDGEMENTS}

This research was funded by the Scientific Research Fund of the Ministry of Education and Science of Bulgaria (SRF-MESB), grant numbers KP-06-OPR06/2/18.12.2018 and KP-06OPR03/18/19.12.2018.

\section{REFERENCES}

Bernard C., Ballot A., Thomazeau S., Maloufi S., Furey A., Mankiewicz-BoczeK I., PaWlikSkowrońska B., Capelli C., Salmazo N., 2017: Appendix 2. Cyanobacteria associated with the production of cyanotoxins. - In: Meriluoto J., Spoof L., Codd J. (eds), Handbook of Cyanobacterial Monitoring and Cyanotoxin Analysis: 501-525. - Chichester.

BLAST, 2021: The Basic Local Alignment Search Tool. https://blast.ncbi.nlm.nih.gov/Blast.cgi [Accessed 12 January 2021].

Bouaicha N., Miles C.O., Beach D.G., Labidi Z., Duabri A., Benayache N.Y., Nguyen-Quang T., 2019: Structural diversity, characterization and toxicology of microcystins. - Toxins, 11(12): 714.

Carey C.C., Ibelings B.W., Hoffmann E.P., HamilTON D.P., BRookes J.D., 2012: Eco-physiological adaptations that favour freshwater cyanobacteria in a changing climate. - Water Research, 46(5): 1394-1407.

Catherine Q., Wood S., Echenigue-Subiabre I., Heath M., Villeneuve A., Humbert J.-F., 2013: A review of current knowledge on toxic benthic freshwater cyanobacteria - ecology, toxin production and risk management. - Water Research, 47(15): 5464-5479.

Catherine A., Bernard C., Spoof L., Bruno M., 2017: Microcystins and nodularins. - In: Meriluoto J., Spoof L., Codd J. (eds), Handbook of cyanobacterial monitoring and cyanotoxin analysis: 109-126. - Chichester. 
Chapman A., Foss A., 2020: Potentially toxigenic (PTOC) Cyanobacteria List. Technical Report, Last updated 27 February 2020. - Green Water Laboratories: 1-13.

Davis T.W., Berry D.L., Boyer G.L., Gobler C.J., 2009: The effects of temperature and nutrients on the growth and dynamics of toxic and nontoxic strains of Microcystis during cyanobacteria blooms. - Harmful Algae, 8(5): 715-725.

DEsCy J.P., 2017: SOP5: Estimation of cyanobacteria biomass by marker pigment analysis. - In: MERiluoto J., Spoof L., Codd J. (eds), Handbook of cyanobacterial monitoring and cyanotoxin analysis: 343-349. - Chichester.

Descy J.-P., Leprieur F., Pirlot S., LeporcQ B., VanWichelen J., Peretyatko A., Teissier S., Codd G.A., Triest L., Vyverman W., Wilmotte A., 2016: Identifying the factors determining blooms of cyanobacteria in a set of shallow lakes. - Ecological Informatics, 34: 129-138.

Descy J.-P., Stoyneva-Gärtner M.P., Uzunov B.A., Dimitrova P.H., Pavlova V.Ts., Gärtner G., 2018: Studies on cyanoprokaryotes of the water bodies along the Bulgarian Black Sea Coast (1890-2017): a review, with special reference to new, rare and harmful taxa. - Acta Zoologica Bulgarica, no Supplementum 11: 43-52.

Flores N.M., Miller T.R., Stockwell J.D., 2018: A global analysis of the relationship between concentrations of microcystins in water and fish. Frontiers in Marine Science, 5: 30.

Foulds I.V., Granacki A., Xiao C., Krull U.J., CastLe A., Horgen P.A., 2002: Quantification of microcystin-producing cyanobacteria and E. coli in water by 5 '-nuclease PCR. - Journal of Applied Microbiology, 93(5): 825-834.

GeitLer L., 1931: Cyanophyceae. - In: Rabenhorst L. (ed.), Kryptogamen-Flora von Deutschland, Österreich und der Schweiz, 2nd ed.: 289-672. Leipzig.

Geitler L., 1942: Schizophyta: Klasse Schizophyceae. - In: Engler A., Prantl K. (eds), Die natürlichen Pflanzenfamilien, Sweite Auflage: 1-232. Leipzig.

Genuário D.B., Lorenzi A.S., Agujaro L.F., Lima Isaac R. De, Paiva Azevedo M.T. De, Neto R.C., FIORE M.F., 2016: Cyanobacterial community and microcystin production in a recreational reservoir with constant Microcystis blooms. - Hydrobiologia, 779: 105-125.

Gkelis S., Zaoutsos N., 2014: Cyanotoxin occurrence and potentially toxin producing cyanobacteria in freshwaters of Greece: a multi-disciplinary approach. - Toxicon, 78: 1-9.

Gollerbakh M.M., Kossinskaya E.K., PolyansKIY V.I., 1953: Manual of freshwater algae of the USSR, 2. Blue-green algae. - Moscow.

Guiry M.D., Guiry G.M., 2021: AlgaeBase. Worldwide electronic publication, National University of Ireland, Galway. - http://www.algaebase.org [Accessed 26 January 2021].

Hartnell D.M., Chapman I.J., Taylor N.G.H., Esteban G.F., Turner A.D., Franklin D.J., 2020: Cyanobacterial abundance and microcystin profiles in two southern British lakes: the importance of abiotic and biotic interactions. - Toxins, 12(8): 503.

Ibelings B.W., Backerb L.C., KardinaAl W.E.A., Chorus I., 2014: Current approaches to cyanotoxin risk assessment and risk management around the globe. - Harmful Algae, 40: 63-74.

Jankowiak J.T., HatTEnRATH-Lehmann B.J., KRAMER M.L., Gobler C.J., 2019: Deciphering the effects of nitrogen, phosphorus, and temperature on cyanobacterial bloom intensification, diversity, and toxicity in western Lake Erie. - Limnology and Oceanography, 64(3): 1347-1370.

Joung S.-H., Oн H.-M., Ko S.-R., Aнn C.-Y., 2011: Correlations between environmental factors and toxic and non-toxic Microcystis dynamics during bloom in Daechung Reservoir, Korea. - Harmful Algae, 10(2): 188-193.

Jungblut A-D., Neilan B.A., 2006: Molecular identification and evolution of the cyclic peptide hepatotoxins, microcystin and nodularin synthetase genes in three orders of cyanobacteria. - Archives of Microbiology, 185: 107-114.

KardinaAl W.E.A., Janse I., Kamst-van Agterveld M., Meima M., Snoek J., Mur L.R., HuisMAN J., ZwART G., VisSER P.M., 2007: Microcystis genotype succession in relation to microcystin concentrations in freshwater lakes. - Aquatic Microbial Ecology, 48(1): 1-12.

Köker L., Akçaalan R., Albay M., Neilan B.A., 2017: Molecular detection of hepatotoxic cyanobacteria in inland water bodies of the Marmara 
Region, Turkey. - Advances in Oceanography and Limnology, 8(1): 52-60.

KomÁREK J., 1984: Sobre las cianofíceas de Cuba: (3) Especies planctónicas que forman florecimientos de las aguas. - Acta Botanica Cubana, 19: 1-33.

KomÁreK J., 2016: A polyphasic approach for the taxonomy of cyanobacteria: principles and applications. - European Journal of Phycology, 51(3): 346-353.

KomÁreK J., 2018: Several problems of the polyphasic approach in the modern cyanobacterial system. - Hydrobiologia, 811: 7-17.

Komárek J., Anagnostidis K., 1998: Cyanoprokaryota 1. Teil: : Chroococcales. - In: EtтL H., Gerloff J., Heynig H., Mollenhauer D. (eds), Süßwasserflora von Mitteleuropa, 19(1): 1-556. Jena-Stuttgart-Lübek-Ulm.

KomÁreK J., KomÁrková J., 2002: Review of the European Microcystis morphospecies (Cyanoprokaryotes) from nature. - Czech Phycology, 2: 1-24.

Komárek J., Kastovsky J., Mares J., Johansen J.R., 2014: Taxonomic classification of cyanoprokaryotes (cyanobacterial genera, using a polyphasic approach. - Preslia, 86: 295-335.

Kormas K. Ar., Gkelis S., Vardaka E., MoustakaGouni M., 2011: Morphological and molecular analysis of bloom-forming Cyanobacteria in two eutrophic, shallow Mediterranean lakes. - Limnologica, 41(3): 167-173.

Lehman P.W., Marr K., Boyer G.L., Acuna S., Teн S.J., 2013: Long-term trends and causal factors associated with Microcystis abundance and toxicity in San Francisco Estuary and implications for climate change impacts. - Hydrobiologia, 718: 141-158.

Le Manach S., Duval C., Marie A., Duediat C., Catherine A., Edery M., Bernard C., Marie B., 2019: Global metabolomic characterizations of Microcystis spp. Highlights clonal diversity in natural bloom-forming populations and expands metabolite structural diversity. - Frontiers in Microbiology, 10: 791.

Liu Y., Tan W., Wu X., Wu Z., Yu G., Li R., 2011: First report of microcystin production in Microcystis smithii Komárek and Anagnostidis (Cyanobacteria) from a water bloom in Eastern China. - Journal of Environmental Sciences, 23(1): 102-107.
Lymperopoulou D.S., Kormas K.Ar., MoustakaGouni M., Karagouni A.D., 2011: Diversity of cyanobacterial phylotypes in a Mediterranean drinking water reservoir (Marathonas, Greece). Environmental Monitoring and Assessment, 173: 155-165.

Lyon-Colbert A., Su S., Cude C., 2018: A systematic literature review for evidence of Aphanizomenon flos-aquae toxigenicity in recreational waters and toxicity of dietary supplements: 2000-2017. Toxins, 10(7): 254.

Mackey M.D., Mackey D.J., Higgins H.W., Wright S.W., 1996: CHEMTAX -- a program for estimating class abundances from chemical markers: application to HPLC measurements of phytoplankton. - Marine Ecology Progress Series, 144: 265-283.

Massey I.Y., Wu P., Wei J., Luo J., Ding P., Wei H., YANG F., 2020: A mini-review on detection methods of microcystins. - Toxins 12(10): 641.

Merel S., Walker D., Chicana R., Snyder S., BauRÈs E., ThOMAs O., 2013: State of knowledge and concerns on cyanobacterial blooms and cyanotoxins. - Environment International, 59: 303-327.

Meriluoto J., Blaha L., Bojadzija G., Bormans M., Brient L., Codd G.A., Drobac D., FaAssen E.J., Fastner J., Anastasia H., Ibelings B.W., Kaloudis T., Kokocinski M., Kurmayer R., Pantelić D., Quesada A., Salmaso N., Tokodi N., Triantis T.M., Visser P.M., SvirČEv Z., 2017: Toxic cyanobacteria and cyanotoxins in European waters - recent progress achieved through the CYANOCOST Action and challenges for further research. - Advances in Oceanography and Limnology, 8(1): 161-178.

Michev T., Stoyneva M. (eds), 2007: Inventory of Bulgarian wetlands and their biodiversity. - Sofia.

Namikoshi M., Rinehart K.L., SAKai R., Stotts R.R., Dahlem A.M., Beasley V.R., Carmichael W.W., Evans W.R., 1992: Identification of 12 hepatotoxins from a homer lake bloom of the cyanobacteria Microcystis aeruginosa, Microcystis viridis, and Microcystis wesenbergii: nine new microcystins. - The Journal of Organic Chemistry, 57(3): 866-872.

NCBI, 2021: National Centre for Biotechnology Information. U.S. National Library of Medicine. - 
https://www.ncbi.nlm.nih.gov/ [Accessed 24 October 2019].

Paerl H.W., Huisman J., 2008: Blooms like it hot. Science, 320(5872): 57-58.

Pavlova V., Stoyneva M., Georgieva V., Donchev D., Spoof L., Meriluoto J., Bratanova Z., KaRADJOVA I., 2014: New records of microcystins in some Bulgarian water bodies of health and conservational importance. - Journal of Water Resource and Protection, 6(5): 446-453.

Pelaez M., Antoniou M.G., He X., Dionysiou D.D., Cruz A.A. de la, Tsimeli K., Triantis T., Hiskia A., Kaloudis T., Williams C., Aubel M., Chapman A., Foss A., Khan U., O’Shea K.E., Westric J., 2010: Sources and occurrence of cyanotoxins worldwide. - In: FATTA-KAssinos D., Bester K., Kümmerer, K. (eds), Xenobiotics in the urban water cycle. Mass flows, environmental processes, mitigation and treatment strategies. Environmental Pollution, 16: 101-127. - Dordrecht.

Radkova M., Stefanova K., Uzunov B., Gärtner G., StOYNEVA-GÄRTNER M., 2020: Morphological and molecular identification of microcystin-producing Cyanobacteria in nine shallow Bulgarian water bodies. - Toxins, 12(1): 39 .

Rantala A., Rajaniemi-Wacklin P., Lyra C., Lepisto L., Rintala J., Mankiewicz-Boczek J., SivoNEN K., 2006: Detection of microcystin-producing Cyanobacteria in Finnish lakes with genus-specific microcystin synthetase gene E (mcyE) PCR and associations with environmental factors. Applied and Environmental Microbiology, 72(9): 6101-6110.

ReYnolds C.S., 2006: The ecology of phytoplankton. - Cambridge.

Rotт E., 1981: Some results from phytoplankton counting intercalibration. - Schweizerische Zeitschrift für Hydrologie, 43: 34-62.

SARMENTo H., Descy J.-P., 2008: Use of marker pigments and functional groups for assessing the status of phytoplankton assemblages in lakes. Journal of Applied Phycology, 20: 1001-1011.

Scherer P.I., Raeder U., Geist J., Zwirglmaier K., 2017: Influence of temperature, mixing, and addition of microcystin-LR on microcystin gene expression in Microcystis aeruginosa. - MicrobiologyOpen, 6(1): e00393.
Srivastava A., Ahn C.-Y., Asthana R.K., Lee H.-G., Он Н.-M., 2015: Status, alert system, and prediction of cyanobacterial bloom in South Korea. BioMed Research International, 2015: 584696.

StARMACH K., 1966: Cyanophyta-Sinice. Glaucophyta-Glaukofity. - Warszawa.

Stefanova K., Radkova M., Uzunov B., Gärtner G., Stoyneva-Gärtner M., 2020: Pilot search for cylindrospermopsin-producers in nine shallow Bulgarian waterbodies reveals nontoxic strains of Raphidiopsis raciborskii, $R$. mediterranea and Chrysosporum bergii. - Biotechnology and Biotechnological Equipment, 34(1): 384-394.

Stoyneva M.P., Descy J.-P., Vyverman W., 2007: Green algae in Lake Tanganyika: is morphological variation a response to seasonal changes? Hydrobiologia, 578: 7-16.

Stoyneva-Gärtner M., Uzunov B., Dimitrova P., Pavlova V., 2017a: Algal toxins - new risk factors for national security in Bulgaria. - Proceedings of the Actual problems of the security, Veliko Turnovo, Bulgaria, 26-27 October. - Veliko Turnovo.

Stoyneva-Gärtner M.P., Descy J.-P., Latli A., Uzunov B., Pavlova V., Bratanova Zl., Babica P., Maršálek B., Meriluoto J., Spoof L., 2017b: Assessment of cyanoprokaryote blooms and of cyanotoxins in Bulgaria in a 15-years period (2000-2015). - Advances in Oceanography and Limnology, 8(1): 131-152.

Stoyneva-Gärtner M.P., Uzunov B.A., Descy J.-P., Gärtner G., Draganova P.H., Borisova C.I., Pavlova V., Mitreva M., 2019: Pilot application of drone-observations and pigment marker detection by HPLC in the studies of CyanoHABs in Bulgarian inland waters. - Marine and Freshwater Research, 71(5): 606-616.

Stoyneva-Gärtner M., Stefanova K., Descy J.-P., Uzunov B., Radkova M., Pavlova V., Mitreva M., GÄrtner G., 2021: Microcystis aeruginosa and $M$. wesenbergii were the primary planktonic microcystin producers in several Bulgarian waterbodies (August 2019). - Applied Sciences, 11(1): 357.

Svirčev Z., Lalić D., Savić G.B., Tokodi N., Backović D.D., Chen L., Meriluoto J., CodD G.A., 2019. Global geographical and historical overview of cyanotoxin distribution and 
cyanobacterial poisonings. - Archives of Toxicology, 93: 2429-2481.

Š́ejnohová L., Maršálek B., 2012: Microcystis. - In: Whitton B.A. (ed.), Ecology of Cyanobacteria II. Their diversity in space and time: 195-228. Dordrecht.

Tamura K., Stecher G., Peterson D., Filipski A., KumAR S., 2013: MEGA6: Molecular evolutionary genetics analysis. Version 6.0. - Molecular Biology and Evolution 30(12): 2725-2729.

Tavera R., Novel E., López S., 2013: Cyanoporkaryora (Cyanobacteria) in karst environments in Yukatan, Mexico. - Botanical Sciences, 91(1): 27-52.

Turland N.J., Wiersema J.H., Barrie F.R., Greuter W., Hawksworth D.L., Herendeen P.S., Knapp S., Kusber W.-H., Li D.-Z., Marhold K., May T.W., McNeill J., Monro A.M., Prado J., Price M.J., Smith G.F. (eds), 2018: International Code of Nomenclature for algae, fungi, and plants (Shenzhen Code) adopted by the Nineteenth International Botanical Congress Shenzhen, China, July 2017. - Glashütten.

Turner A.D., Dhanji-Rapkova M., O’Neill A.,
Coates L., Lewis A., Lewis K., 2018: Analysis of microcystins in cyanobacterial blooms from freshwater bodies in England. - Toxins, 10(1): 39.

Vézie C., Rapala J., Vaitomaa J., Seitsonen J., SivoNEN K., 2002: Effect of nitrogen and phosphorus on growth of toxic and nontoxic Microcystis strains and on intracellular microcystin concentrations. - Microbial Ecology, 43(4): 443-454.

WhitTon B.A. (ed.), 2012: Ecology of Cyanobacteria II: their diversity in space and time, 2 nd ed. Dordrecht.

Wilhelm S.W., Bullerjahn G.S., McKay R.M.L., 2020: The complicated and confusing ecology of Microcystis blooms. - mBio, 11(3): e00529-20.

Wright S.W., JefFrey S.W., 2006: Pigment markers for phytoplankton production. - In: Volkman J.K. (ed.), Marine organic matter: biomarkers, isotopes and DNA. The handbook of environmental chemistry, 2N: 71-104. - Berlin-Heidelberg.

Zanchett G., Oliveira-Filho E.C., 2013: Cyanobacteria and cyanotoxins: from impacts on aquatic ecosystems and human health to anticarcinogenic effects. - Toxins, 5(10): 1896-1917.

\section{MICROCYSTIS RŪŠYS IR TOKSINIAI JŲ KAMIENAI DEŠIMTIES VANDENS TELKINIŲ FITOPLANKTONE BULGARIJOJE}

\section{Blagoy UZUNOV, Katerina STEFANOVA, Mariana RADKOVA, Jean-Pierre DESCY, Georg GÄRTNER, Maya STOYNEVA-GÄRTNER}

\section{Santrauka}

Darbo tikslas buvo nustatyti potencialių mikrocistinu gamintojų ivvairovę, ju toksiniu kamienu paplitimą, akcentuojant žydejjimus sukeliančias $M i$ crocystis genties melsvabakteres. Microcystis tyrimai atlikti dešimtyje Bulgarijos vandens telkinių: Ezerets, Durankulako ežeruose ir Koprinka vandens saugykloje Microcystis melsvabakterès buvo tirtos anksčiau, Shilkovtsi, Zhrebchevo, Suedinenie vandens saugykloje iki šiol nebuvo rastas; Malka Smolnitsa, Plachidol 2, Preselka, Duvanli vandens saugykloje pirmą kartą buvo tirta fitoplanktono struktūra. Vasaros fitoplanktono struktūra buvo tiriama šviesiniu mikroskopu, pigmentai - aukšto slègio chromatografijos metodu, o PGR amplifikacijos pagalba nustatyti $m c y B$ ir $m c y E$ genai. Šviesinès mikroskopijos ir aukšto slėgio chromatografijos tyrimų duomenys parode, kad devyniuose iš 10-ties tirtu vandens telkinių cianoprokariotai fitoplanktono sudètyje sudarè reikšmingą gausumo (29\%) ir biomasès $(15-87 \%)$ dali. Šviesinès mikroskopijos pagalba buvo identifikuotos rūšys: Microcystis aeruginosa, M. natans, M. smithii, M. wesenbergii, Microcystis spp., M. cf. comperei ir M. pseudofilamentosa. Pastarosios dvi tropikams būdingos rūšys šalyje buvo rastos pirmą kartą. Bendroje fitoplanktono įvairoveje ir jos biomasejje Microcystis sudarè nedidelę dalį. Molekuliniais tyrimais nustatyti 57 toksiniai šios genties melsvabakterių kamienai, kuriu sekos pagal NCBI duomenų bazę buvo artimiausios $M$. aeruginosa ir $M$. wesenbergii rūšsims. 